\title{
Hyenism in Ants: Non-Target Ants Profit From Polyergus rufescens Raids (Hymenoptera: Formicidae)
}

by

\author{
Pavel Pech
}

\begin{abstract}
The presence of slavemaker ants alters the structure of the ant community. The influence of slavemakers on non-host ants is believed to be indirect, via changing competitive interactions among the ants. According to my observation Myrmica sabuleti (and probably also Lasius alienus) profited from a Polyergus rufescens raid against a Formica fusca nest. Both non-host species collected F. fusca corpses. These carcasses were used as food in the case of M. sabuleti at least. M. sabuleti profited substantially from the Polyergus raid because the dry biomass weight of the collected $F$. fusca carcasses was approximately half of the dry biomass weight of all $M$. sabuleti workers.

Key words: ants, Formicidae, profit, slavery, social parasitism
\end{abstract}

It has been shown that the structure of an ant community is affected by both top-competitors and slavemakers (Puntilla et al. 1996). The influence of slavemakers on non-host species is considered to be indirect, taking affect via changing competitive interactions among the ants. The socially parasitic ant Polyergus rufescens (Latreille, 1798) is a slave-maker who uses ants from the subgenus Serviformica spp. as a host. In this paper I refer to the direct nutrient benefit gained by non-host ants from Polyergus rufescens raiding.

I observed a raid of P. rufescens on a Formica fusca (Linnaeus, 1758) nest on the green of Havraníky (a village in South Moravia) in the afternoon of 31.5.2011. The nests were approximately $15 \mathrm{~m}$ apart. The raid was already in progress when I arrived: the dead queen and many dead and dying F. fusca workers lay on the surface of the attacked nest and Polyergus workers were carrying pupae away into their own nest. Several $F$. fusca workers that had escaped the attack stormed about, in some cases carrying a rescued pupae.

University of Hradec Králové, Faculty of Science, Rokitanského 62, 500 03, Czech Republic E-mail: pavelpech1@centrum.cz 
There was a nest of Myrmica sabuleti (Meinert, 1861) in the vicinity of the attacked $F$. fusca nest (approximately $20 \mathrm{~cm}$ away). M. sabuleti workers appeared to increase their activity levels as the number of Polyergus workers on the attacked nest decreased. Many $M$. sabuleti workers came to the attacked nest and transported carcasses into their own nest. Moreover, M. sabuleti workers behaved very agressively towards F. fusca workers that had escaped the $P$. rufescens raid and attacked them with open mandibles. Nevertheless, the F. fusca moved much faster than the M. sabuleti and escaped in all the cases that I observed.

During the next day there were still some F. fusca carcasses on the plundered F. fusca nest. The M. sabuleti paid no attention to these carcasses. Instead I observed several Lasius alienus (Förster, 1850) workers transporting them away.

I dug up and searched all the nests in the site: the attacked F. fusca nest, $M$. sabuleti nest and L. alienus nests. There were 127 workers, 8 pupae, and 27 larvae of M. sabuleti, and 27 dead workers of $F$. fusca in the M. sabuleti nest. Most $F$. fusca carcasses had been placed in a chamber with $M$. sabuleti larvae and these corpses were partly cut into pieces. The L. alienus nest contained only $3 L$. alienus workers; it was not a proper nest but rather a temporary station. There was $12 \mathrm{dead} F$. fusca workers placed in the entrance and a further stock of corpses above the entrance of the station.

There were 14 carcasses of $F$. fusca workers and 1 queen still on the surface of the former $F$. fusca nest. I found nothing inside this nest except 5 forgotten F. fusca pupae.

I weighed the dry biomass of $M$. sabuleti workers and the carcasses of F. fusca. The total weight of the 27 F. fusca workers was $0.0558 \mathrm{~g}$ and the total weight of the 127 M. sabuleti workers was $0.1194 \mathrm{~g}$. It seems that $M$. sabulet $i$ benefited substantially: The weight of $F$. fusca carcasses in $M$. sabuleti nest was approximately half of the weight of all the $M$. sabuleti workers. It was not possible to make the same calculation in the case of $L$. alienus, because it was not clear which nest the station belonged to.

\section{CONCLUSIONS}

Non-host ants can benefit from the presence of slavemaker ants indirectly, through the reduction of competition (Punttila et al. 1996), or directly, 
through the consumption of the victims of slavemakers' raids. Independently of this observation it is known that ants are the most efficient of all invertebrate carcass scavengers (Fellers \& Fellers 1982; Retana et al. 1991), and it is probable that non-host ants collect most of the victims of slavemaker raids. Clearly the supply of this food to non-host ants is occasional only. On the other hand, with regard to the range and frequecy of Polyergus raids, the amount of food gained is not negligible.

The observation of the aggressive behavior of $M$. sabuleti towards escaping $F$. fusca is interesting. I have never observed or read about such aggressiveness of M. sabuleti to $F$. fusca. The close vicinity of both nests confirms a non-conflict relationship between both nests of these species. It seems that the aggressive behavior of $M$. sabuleti to $F$. fusca is related to the unfavorable situation of the F. fusca colony attacked by Polyergus.

\section{ACKNOWLEDGMENTS}

I wish to thank C. Steer and I. Oulehlová for improving the English version of the manuscript.

\section{REFERENCES}

Fellers, G.M., \& J.H. Fellers. 1982. Scavenging rates of invertebrates in an eastern deciduous forest. American Midland Naturalist 107: 389-392.

Mori, A., C. Castracani, D.A. Grasso, F. Le Moli, \& R. Visicchio 2001. Glandular sources of recruitment, trail, and propaganda semiochemicals in the slave-making ant Polyergus rufescens. Ethology, Ecology and Evolution 13: 361-372.

Punttila, P., Y. Haila, \& H. Tukia 1996. Ant communities in taiga clearcuts: Habitat effects and species interactions. Ecography 19: 16-28.

Retana, J., X. Cerda \& X. Espadaler 1991. Arthropod corpses in a temperate grassland: a limited supply. Holarctic Ecology 14: 63-67.

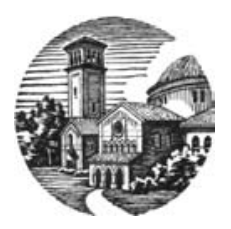


